\title{
Diagnosis dan Penatalaksanaan Benda Asing Baterai Kancing pada Kavum Nasi
}

\author{
Yolazenia,${ }^{1 *}$ Elfahmi ${ }^{2}$
}

\begin{abstract}
Nasal foreign body is common case that often seen in children. Button battery is one of nasal foreign body that rarely seen and most commonly occur in children 2-5 year-old. A nasal button battery is one of otorhinolaryngological emergency because it can lead to severe damage, necrosis, and perforation of nasal septum. Therefore, early diagnosis and prompttreatment was needed. A case of button battery in nasal cavity in a 3 year-old boy was reported, which had been performed an extraction of foreign body and irrigation under general anesthesia.
\end{abstract}

Keywords: nasal foreign body, button battery, perforation of nasal septum

Benda asing di hidung merupakan kasus yang sering ditemukan pada anak-anak. Anak-anak cenderung mempunyai kebiasaan memasukkan suatu benda yang kecil pada lubang atau rongga pada tubuhnya terutama pada lubang hidung disebabkan rasa ingin tahu, kurangnya pengawasan orang tua dan tersedianya benda tersebut di sekitar mereka. Kasus tersebut sering ditemukan pada anak-anak, pada orang dewasa kasus ini umumnya dialami oleh mereka yang mengalami retardasi mental atau penderita gangguan jiwa. Benda asing hidung yang sering ditemukan antara lain manik-manik, kancing baju, bagian dari mainan, lilin plastisin, kertas, batu, kacang, kapur, dan baterai. ${ }^{1-3}$

Prevalensi kasus benda asing hidung lebih banyak ditemukan pada laki-laki dibanding perempuan. Pada anak-anak insiden tertinggi ditemukan pada usia 2-5 tahun. Lokasi benda asing yang paling sering adalah pada anterior konka media atau di bawah konka inferior (gambar 1). Benda asing unilateral lebih sering ditemukan pada sisi kanan dibanding sisi kiri. ${ }^{1,2}$

\footnotetext{
1 Penulis untuk korespondensi: Fakultas Kedokteran Universitas Riau, email: yolazenia@lecturer.unri.ac.id

2 Bagian THT-KL, RSUD Solok
}

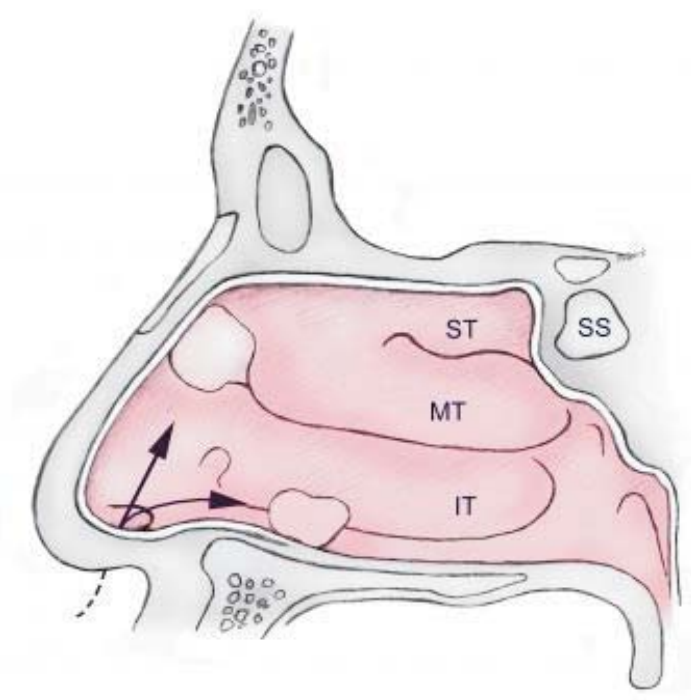

Galluar 1. Lokası venua asıng paua KavuIn Ilası $(\boldsymbol{1} \boldsymbol{1}=$ inferior turbinate; $M T=$ middle turbinate; $S S=$ sphenoid sinus; $S T=$ superior turbinate). ${ }^{2}$

Benda asing dapat diklasifikasikan menjadi benda asing anorganik dan organik. Benda asing anorganik dapat berupa plastik atau metal seperti manik-manik dan bagian dari mainan. Benda asing ini sering tanpa gejala dan dapat ditemukan secara kebetulan. Benda asing organik seperti makanan, karet, kayu, busa bersifat lebih iritatif terhadap mukosa hidung sehingga menimbulkan gejala yang lebih dini. ${ }^{1,2}$ 
Benda asing yang sudah lama di dalam kavum nasi yang tidak diketahui sebelumnya akan dilapisi oleh kalsium, magnesium, fosfat, atau karbonat dan menjadi rinolit. Rinolit menyerupai batu, bersifat radioopak dan sering ditemukan pada lantai kavum nasi. $^{1,2}$

Baterai kancing merupakan suatu benda kecil dan bersinar yang ditemukan pada banyak mainan, sehingga merupakan benda yang menarik bagi anakanak untuk dimasukkan ke lubang hidung. Baterai kancing terbuat dari metal dan mengandung berbagai macam bahan kimia yang bersifat korosif bila berkontak dengan lingkungan lembab seperti rongga hidung. Baterai kancing pada kavum nasi harus segera dikeluarkan dan dievaluasi komplikasi yang diakibatkannya. ${ }^{1,3}$

Dalam mendiagnosis benda asing hidung penting ditanyakan apa ada saksi yang melihat anak memasukkannya. Sering diagnosis benda asing hidung terlambat karena tidak adanya saksi yang melihat. Pada kasus yang terlambat gejala yang paling umum muncul adalah adanya sekret hidung unilateral. ${ }^{1,2}$ Kecurigaan pada benda asing hidung harus dipikirkan pada pasien dengan gejala iritasi hidung, nafas bau, epistaksis, bersin-bersin, dan gejala sinusitis. Pemeriksaan rinoskopi anterior menggunakan spekulum hidung dengan visualisasi maksimal menggunakan lampu kepala dilakukan untuk melihat adanya benda asing hidung. Pemeriksaan radiologi pada kebanyakan kasus tidak diperlukan. Kebanyakan benda asing tersebut bersifat radiolusen kecuali benda asing metal. Untuk menyingkirkan kemungkinan diagnosis lain (seperti sinusitis atau tumor) perlu dipertimbangkan untuk pemeriksaan tomografi komputer (CT Scan) ${ }^{1,2}$

Benda asing hidung harus diekstraksi untuk mengeluarkannya. Ekstraksi benda asing hidung diperlukan keterampilan dan pengalaman tersendiri. Usaha mengeluarkan benda asing yang berulangulang dapat menyebabkan terjadinya trauma dan menyebabkan benda asing berpindah atau tertanam lebih dalam ke tempat yang lebih sukar untuk dijangkau. Sebelum melakukan ekstraksi benda asing, perlu dilakukan persiapan yang optimal meliputi peralatan yang dibutuhkan dan mengatur posisi pasien. Pada pasien yang tidak kooperatif dapat dilakukan dalam anestesi umum. ${ }^{1,2,4}$
Ada beberapa cara ekstraksi benda asing hidung yaitu menggunakan instrumentasi langsung seperti klem hemostat, forsep aligator, forsep bayonet danpengait (hook). Pengait sering digunakan untuk benda yang mudah terlihat tapi sulit dijangkau. Pengait diletakkan dibelakang benda asing lalu diputar sehingga sudutnya berada di belakang benda, lalu benda ditarik keluar. Metoda lain bisa menggunakan kateter balon, tekanan positif, suction, lem dan magnet. Pilihan metoda tergantung dari jenis benda asing, alat yang tersedia, dan pengalaman klinisi. ${ }^{1,2}$

\section{LAPORAN KASUS}

Seorang pasien laki-laki usia 3 tahun diantar orang tuanya datang ke poliklinik THT-KL RSUD Solok pada tanggal 21 Agustus 2015 dengan keluhan utama masuk benda asing pada lubang hidung sebelah kanan sejak 1 hari yang lalu. Sebelumnya pasien sedang bermain sendiri tiba-tiba mengatakan pada ibunya bahwa hidung sebelah kanannya sakit. Ibu pasien melihat seperti ada benda asing pada lubang hidung kanan pasien, tapi tidak tahu pasti apa benda tersebut. Tidak ada yang melihat sewaktu pasien memasukkan benda asing ke dalam lubang hidungnya. Pasien dibawa ke rumah sakit daerah, dicoba dikeluarkan di sana tapi tidak berhasil lalu dirujuk ke RSUD Solok. Terdapat sekret coklat kehitaman dari lubang hidung kanan pasien sejak 6 jam yang lalu. Tidak ada keluar darah dari hidung, tidak ada riwayat tersedak, tidak ada sesak nafas dan tidak ada mual-muntah.

Pada pemeriksaan fisik dijumpai keadaan umum pasien sedang, komposmentis tidak kooperatif, nadi $90 \mathrm{x} /$ menit, nafas $22 \mathrm{x} / \mathrm{menit}$, dan suhu tidak demam. Berat badan pasien $14 \mathrm{~kg}$. Pada pemeriksaan dada tidak tampak adanya retraksi, dan tidak ada stridor maupun wheezing.

Pada pemeriksaan THT, tidak ditemukan kelainan pada telinga dan tenggorok. Pada pemeriksaan rinoskopi anterior, pada kavum nasi dekstra didapatkan kavum nasi sempit, tampak sekret coklat kehitaman, jaringan nekrotik pada konka inferior (KI) dan septum, tampak benda asing berwarna keperakan antara KI dan septum, konka media (KM) sukar dinilai. Pada kavum nasi sinistra didapatkan kavum nasi lapang, konka inferior dan 
konka media eutrofi, tidak ada sekret dan tidak ada benda asing.

Pasien didiagnosis dengan benda asing (suspek baterai kancing) pada kavum nasi dekstra dan direncanakan untuk ekstraksi benda asing dalam anestesi umum. Pasien dipuasakan 6 jam sebelum tindakan dan dikonsulkan ke bagian anestesi. Pasien diberi terapi cefotaksim 2 x $350 \mathrm{mg}$ (iv), dan parasetamol 3 x $180 \mathrm{mg}$ (oral).

Ekstraksi benda asing dilakukan pada pukul 15.00 WIB. Pasien tidur telentang di meja operasi dalam anestesi umum. Dilakukan aseptik/antiseptik lapangan operasi. Dimasukkan oral packing. Evaluasi kavum nasi dekstra menggunakan spekulum hidung, tampak KI edema, KM sukar dinilai, terdapat sekret, krusta kehitaman dan jaringan nekrotik sekitar KI dan septum. Sekret dihisap, tampak benda asing berwarna keperakan (baterai kancing) di antara KI dan septum. Baterai diekstraksi menggunakan hook. Ekstraksi berhasil. Jaringan nekrotik dikuret semaksimal mungkin, lalu diirigasi dengan $\mathrm{NaCl} 0,9 \%$. Evaluasi kavum nasi sinistra tampak septum $1 / 3$ tengah berwarna kehitaman, perforasi tidak ada. Dipasang tampon anterior (sofratul + kassa yang diolesi kream kloramfenikol) pada kavum nasi dekstra. Operasi selesai.

Setelah tindakan ekstraksi benda asing, pasien dirawat dan diberi terapi cefotaksim $2 \times 350 \mathrm{mg}$ (iv), parasetamol $3 \times 180 \mathrm{mg}$ (oral). Pada hari ketiga, tampon anterior dibuka. Evaluasi kavum nasi dekstra kavum nasi lapang, terdapat clotting, jaringan nekrotik (+) minimal pada KI dan septum, perforasi septum tidak ada, darah mengalir tidak ada. Pasien diperbolehkan pulang dan diberi terapi parasetamol $3 \times 180 \mathrm{mg}$ (oral) dan amoksisilin $3 \times$ $180 \mathrm{mg}$ (oral) dan dianjurkan kontrol ke poliklinik THT satu minggu lagi.

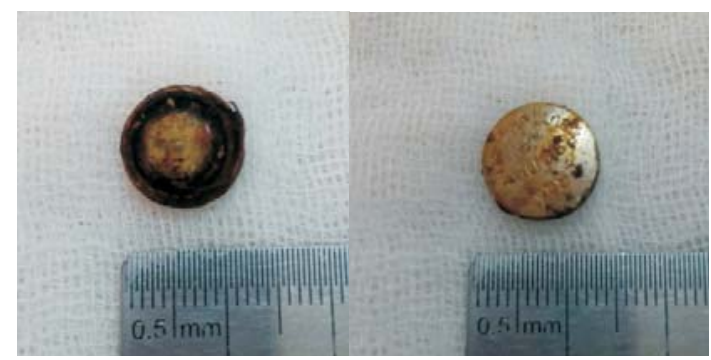

Gambar 2. Baterai kancing setelah diekstraksi dari kavum nasi dekstra.

\section{PEMBAHASAN}

Kasus benda asing (baterai kancing) di kavum nasi dekstra telah dilaporkan pada seorang anak lakilaki usia 3 tahun. Kasus benda asing hidung umumnya ditemukan pada anak usia 2-5 tahun, pada usia ini anak mempunyai kebiasaan memasukkan suatu benda yang kecil pada lubang atau rongga pada tubuhnya terutama pada lubang hidung disebabkan rasa ingin tahunya. Benda asing hidung juga lebih banyak ditemukan pada anak laki-laki dibanding perempuan. Hal ini mungkin disebabkan karena anak laki-laki relatif lebih aktif dan mempunyai rasa ingin tahu yang lebih besar. Benda asing hidung juga lebih banyak ditemukan pada lubang hidung kanan dibanding kiri. Hal ini mungkin disebabkan karena kebanyakan orang merupakan pengguna tangan kanan sehingga juga cenderung memasukkan benda asing ke lubang hidung kanan. ${ }^{1,2}$

Benda asing di hidung biasanya dapat terlihat dari pemeriksaan rinoskopi anterior, tapi pada beberapa kasus jika terjadi edema mukosa atau jaringan granulasi benda asing tersebut dapat tidak terlihat. ${ }^{4}$ Dalam hal ini bila benda asing bersifat radioopak dapat dilakukan pemeriksaan radiologi untuk melihat lokasi benda asing. ${ }^{1}$ Pada kasus ini, benda asing pada pasien dapat terlihat dari pemeriksaan rinoskopi anterior sehingga tidak diperlukan pemeriksaan radiologi.

Baterai kancing banyak digunakan dalam kehidupan sehari-hari seperti pada mainan elektronik, mainan, kalkulator, jam tangan, kamera, alat bantu dengar, laser pointer dan alat elektronik lainnya. Berdasarkan keterangan ibu pasien, baterai kancing yang dimasukkan ke dalam lubang hidung pasien kemungkinan berasal dari permainan laser.

Baterai kancing sebagai benda asing selain pada kavum nasi ditemukan juga di liang telinga dan esofagus atau saluran cerna. ${ }^{5-8}$ Baterai kancing mengandung berbagai macam logam berat seperti merkuri, zinc, perak, nikel, kadmium, mangan, litium dan larutan elektrolit yang bersifat alkali 26$45 \%$ potasium atau sodium hidroksida. ${ }^{5} \mathrm{~B}$ ahanbahan kimia ini dapat menyebabkan nekrosis bila berkontak dengan jaringan manusia yang lembab dan dalam waktu cepat menyebabkan nekrosis jaringan diikuti dengan perforasi (Gambar 3). ${ }^{1}$ 


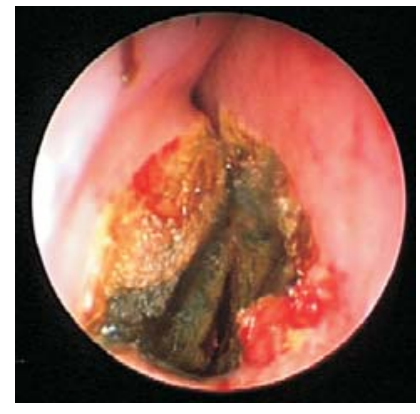

Gambar 3. Baterai kancing pada lantai kavum nasi kanan menyebabkan nekrosis pada konka inferior dan septum. ${ }^{1}$

Ada beberapa teori mekanisme terjadinya kerusakan pada mukosa hidung dan jaringan sekitarnya yang disebabkan baterai kancing pada hidung. Salah satu mekanisme adalah kebocoran isi baterai. Baterai mempunyai sisi anoda dan katoda yang dipisahkan oleh segel plastik (Gambar 4). ${ }^{9}$ Segel plastik ini dapat mengalami korosi dengan mudah pada lingkungan lembab, menyebabkan kebocoran bahan-bahan yang bersifat korosif. Bagian anoda mengandung bahan yang bersifat alkali yaitu sodium atau potasium hidroksida. Hal ini menjelaskan kenapa kerusakan jaringan paling berat pada sisi anoda baterai. Faktor lain yang berperan penting dalam terjadinya komplikasi adalah waktu atau lamanya benda asing berada dalam kavum nasi. ${ }^{9-14}$ Loh et al $^{10}$ melaporkan bahwa 4 dari 6 pasien dengan baterai kancing di hidung mengalami perforasi septum. Waktu tercepat terjadinya perforasi septum adalah $7 \mathrm{jam}$. Lee et al ${ }^{14}$ melaporkan 2 anak dengan baterai kancing di hidung mengalami perforasi septum setelah 8 dan 48 jam.

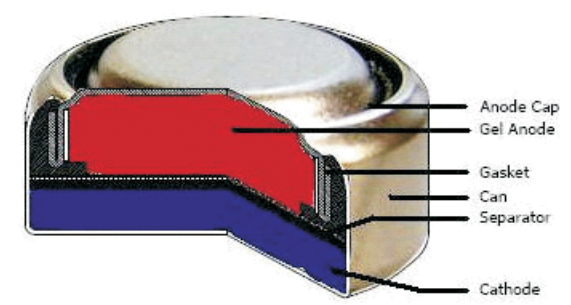

Gambar 4. Gambaran skematik potongan melintang dari baterai kancing. ${ }^{10}$

Mekanisme kerusakan lain adalah terdapatnya arus lokal yang terjadi saat baterai berkontak dengan jaringan mukosa hidung. Elektron yang dihasilkan anoda akan bergabung dengan ion hidrogen jaringan membentuk gas hidrogen. Ion hidroksil yang tersisa akan berkombinasi dengan ion sodium atau potasium menghasilkan produk alkali yang menyebabkan kerusakan pada jaringan sekitarnya.Mekanisme lain adalah terjadinya luka bakar langsungdisebabkan meningkatnya suhu jaringan akibat dari arus langsung mengenai jaringan mukosa hidung. Teori lain mengatakan nekrosis terjadi karena baterai yang tertanam pada hidung dapat menyebabkan tekanan sehingga terjadi iskemia jaringan sehingga timbul nekrosis. ${ }^{9-14}$

Kerusakan yang terjadi pada mukosa hidung yang disebabkan baterai kancing dapat berupa nekrosis mukosa hidung terlokalisir, perforasi septum, selulitis fasial dan nekrosis dinding lateral hidung. ${ }^{4,10}$ Pada kasus ini, jaringan nekrotik terutama ditemukan pada septum nasi dengan perubahan warna juga terlihat pada sisi septum nasi kontralateral disebabkan sisi anoda baterai menempel pada septum nasi.

Benda asing di hidung harus segera dikeluarkan untuk mencegah komplikasi yang ditimbulkannya. Keberhasilan dalam mengeluarkan benda asing hidung tergantung dari beberapa faktor seperti ukuran, bentuk dan tekstur benda asing, waktu, kerjasama pasien, kemampuan visualisasi benda asing dan struktur sekitarnya, trauma pada kavum nasi, peralatan yang tersedia dan keterampilan dokter. ${ }^{1}$ Anestesi umum mungkin diperlukan pada kondisi dimana benda asing terdapat pada bagian posterior hidung dengan risiko terdorong ke nasofaring, jika pasien tidak kooperatif, jika sepertinya akan menyebabkan perdarahan, jika benda asing diduga kuat tapi tidak dapat ditemukan sehingga deperlukan pemeriksaan yang lebih ekstensif. $^{4}$

Setelah baterai dikeluarkan dari hidung harus dilakukan irigasi dengan larutan salin untuk membersihkan bahan-bahan alkali yang keluar dari baterai. ${ }^{15} \mathrm{Pada}$ pasien dilakukan ekstraksi menggunakan pengait dalam anestesi umum disebabkan pasien tidak kooperatif dan benda asing (baterai) sudah tertanam 1 hari (> 24 jam) dan sudah menimbulkan jaringan nekrotik sehinggga dikuatirkan terjadinya perdarahan. Selain itu pada pasien juga direncanakan untuk dilakukan 
pembersihan jaringan nekrotik dan irigasi dengan salin sehingga diperlukan tindakan dalam anestesi umum.

Berdasarkan 4 kasus yang dilaporkan Guidera et $a l^{9}$ menunjukkan bahwa kerusakan mukosa yang disebabkan baterai dapat terjadi hanya dalam waktu 90 menit dan perforasi septum dapat terjadi hanya dalam waktu 4 jam. Oleh karena itu, untuk menghindari terjadinya nekrosis jaringan, baterai dalam kavum nasi harus sudah dikeluarkan dalam waktu sebelum 90 menit. Dalam waktu ini baterai masih bisa dikeluarkan tanpa anestesi umum.

Follow up berkala diperlukan untuk menilai komplikasi jangka panjang seperti perforasi septum, sinekia, ulserasi mukosa dan nekrosis. ${ }^{15}$ Setelah diperbolehkan pulang pasien dianjurkan untuk kontrol ke poliklinik 1 minggu lagi.

\section{KESIMPULAN}

Benda asing baterai kancing merupakan salah satu kegawatdaruratan di bagian THT. Baterai kancing mengandung bahan-bahan logam yang bersifat korosif terutama pada sisi anoda yang bila berkontak dengan lingkungan lembab dapat menimbulkan kerusakan jaringan yang luas. Oleh karena itu perlu edukasi pada orang tua untuk mendidik anaknya supaya tidak memasukkan benda asing pada hidung, meningkatkan pengawasan sewaktu anak bermain dan menjauhkan permainan yang menggunakan baterai kancing dari anak kecil (balita).

\section{DAFTAR PUSTAKA}

1. Fischer JI, Dronen SC. Nasal foreign body. Diakses dari: http:// www.emedicine.medscape.com. Updated: Aug 11,2015 .

2. Kalan A, Tariq M. Foreign body in the nasal cavities: a comprehensive review of the aetiology, diagnostic, pointers, and therapeutic measures. Postgrad Med J 2000;76:484-7.

3. Gabriel OT, Okunade OK, David DA, Mathew AS. Review of nasal foreign bodies in children at a rural federal medical institution in south west, Nigeria. Advances in Medical Sciences 2014;3(1):16-21.
4. Herawati S. Impacted button battery in the nasal cavity. Folia Medica Indonesiana 2004;40(3):139-42.

5. Chan YL, Chang SS, Kao KL, Liao HC, Liaw SJ, Chiu TF, et al. Button battery ingestion: an analysis of 25 cases. Chang Gung Med J 2002;25:169-74.

6. Thabet MH, Basha WM, Askar S. Button battery foreign bodies in children: Hazards, management, and recommendations. Biomed Research International 2013; article id 846091:17.

7. Liao W, Wen G, Zhang X. Button battery intake as foreign body in chinese children. Pediatr Emer Care 2015;31:412-15.

8. Lin VYW, Daniel SJ, Papsin BC. Button battery in the ear, nose and upper aerodigestive tract. Int J Pediatric Otol Rhino Laryngol 2004;68:4739.

9. Guidera AK, Stegehuis HR. Button batteries: the worst case scenario in nasal foreign bodies. NZMJ 2010;123(1313):68-73.

10.Loh WS, Leong JL, Tan HKK. Hazardous foreign bodies: complications and management of button batteries in nose. Ann Otol Rhinol Laryngol 2003;112:379-83.

11.Fannon MP, Hernandez EM, Baxter A. Button battery nasal foreign body: a case report. The American Journal for Nurse Practitioners 2009;13(7):3-8.

12. Okhakhu AL, Okolugbo NE, Onyeagwara NC. Disk battery in the nasal cavity: case series. IJMAMR 2013;1:5-8.

13. Majumdar AB, Sengupta A, Paul SS. A case series of button batteries as nasal foreign bodies among children. Int J Adv Med. 2014;1(3):2736.

14.Lee HM, et al. Nasal septal perforation due to button battery. J Rhinol 2001;8(1):69-72.

15. Kaur J, Ravikumar R, Viswanatha B, Vijayashree MS. An interesting case of button battery causing septal perforation. Research in Otolaryngology 2014;3(6):89-91. 